FACTA UNIVERSITATIS

Series: Physical Education and Sport, Vol. 17, No 3, 2019, pp. 569 - 578

https://doi.org/10.22190/FUPES190315051B

Professional article

\title{
BRANDING AND BRAND AS A FACTOR OF COMPETITIVE ADVANTAGE IN SPORTS
}

\author{
UDC 339.138
}

\begin{abstract}
Srećko Bačevac ${ }^{1}$, Jovan Veselinović ${ }^{1}$, Dragan Životić $^{2}$
${ }^{1}$ Faculty Faculty for Management in Sport, Alfa BK University, Belgrade, Serbia ${ }^{2}$ Faculty of Physical Culture and Sports Management, Singidunum University, Belgrade,

Serbia

Abstract. The purpose of this research is based on the analysis of scientific-theoreticalpractical knowledge in the field of brand management, with special emphasis on the brand as a significant factor of organizational competitive advantage and establishing a leading position in the sports market. By examining a wide variety of theoretical knowledge, we come across definitions that are based on the views of the world's leading marketing experts who point out that the basic function of marketing is brand building. Building, consolidating and expanding the brand require dimensions of clarity, consistency and leadership, adapted to the environment, with particular emphasis on competitive advantage, technology and on establishing a leading position on the market. Referring to the adequate literature, this paper covers the complete branding strategy, starting from the general works that define branding strategy as the most powerful communication tool; from strategies that are based on definitions that the key to success is the achievement of competitive advantage and the establishment of a leading position on the market; towards specific strategies which explore the basic elements of the branding strategy and their impact on the company's business and productivity, as well as the impact on the consumers' awareness.
\end{abstract}

Key words: Brand, Trademark, Competitive Advantage

\section{INTRODUCTION}

Exploring a variety of theoretical knowledge, we find definitions that are based on the stand of the world's leading marketing experts, who point out that the basic functions of marketing are just brand building (Milić, 2014). The brand as a popular phrase originated in the world of communication, advertising and marketing, and as such it does not

Received March 15, 2019/ Accepted December 25, 2019

Corresponding author: Jovan Veselinović

Faculty for Management in Sport, Alfa BK University, Palmira Toljatija 3, 11000 Novi Belgrade, Serbia

Phone: + 381112609754510900 •E-mail: jovan.veselinovic@alfa.edu.rs 
represent what is propagated, but it represents the concept of what satisfies consumer needs (Olins, 2003). To put it simply, the brand represents spotting the values of a product, that is, the recognition of an identity of specific product.

The term "brand" in the literal translation from the English language means a "symbol, design". Actually, a brand is a product or branding process, and as such a branding process represents a function or process of marking, labeling and establishing a trademark.

By exploring the very beginnings of the branding, we encounter many different perspectives. Some authors have determined the beginning of branding even before the new era. If we take into account that every branded product, e.g. Greek olive oil, Indian cashmere, Indian spice curry, Chinese tea, etc., it can be concluded that early history products were brands. Regardless of natural or monetary exchange, each of these products had its value.

What is foreseen here is that productive branding is exclusively a trade in information, or specifically, in ideas, rather than in material goods, which indicates that branding could only be developed after a post-industrial revolution. It is widely believed that branding started, literally, as a method by which ranchers marked their cattle, stamping a hot symbol on the young calf's skin. Thus, the owner secured the recognition of his property (Ruskhoff, 2010). Similarly, contemporary producers mark their goods with a logo and a visual identity in order to differentiate their goods from those of their rivals.

Actually, this is not the start of branding, but it represents the root of the name, because embossing the stamp on the cattle was called "branding." This is, in fact, a material marking of ownership and not the trade of ideas. It is only after the Second World War that we can talk about the real start of branding as we see it today. It started in America, for several reasons. Industrial capacities, developed during the war to meet military needs, have been redirected to meet the consumer needs of the ordinary man; thus there was an overflowing wave of new products that needed to be differentiated from one another. The economic power of an average citizen has increased, and shopping has become a trend. The foundation of the branding production, therefore, dates back to the time when the market began to overflow with uniformized mass production products that practically did not differ from one another; thus the simple pre-war direct sales did not meet the needs of companies. Competitive branding production has become the imperative of the industrial era - in the context of fabricatedness, along with production, and it had to be produced on image-based difference (Klein, 2010).

The basic purpose of this research is based on the analysis of scientific-theoreticalpractical knowledge in the field of brand management, with a special emphasis on the brand as a significant factor of organizational competitive advantage and establishing a leading position in the sports market.

\section{THE DEFINITION OF A BRAND}

The brand can be defined in different ways. By using the Internet and literature, we can find a great number of definitions. The most frequently cited definition belongs to De Chernatony, \& Riley (1998), which was accepted by the American Marketing Association: A brand is a name, term, design, symbol, or a combination of them, intended to identify the goods or services of one seller or group of sellers and to differentiate them from those of the competitors. 
Nowadays, extended versions of this definition can be found, which emphasize the relationship between consumers and products or services. The brand represents a unique and identifiable symbol, the name or trademark that serves to differentiate products and services from that of competitors. At the same time, it represents a physical and emotional driver that creates a relationship between consumers and products or services.

Schultz and Barnes (1999) devised the theory that a brand in the $21^{\text {st }}$ century market is more than a name, term, sign, symbol, or any other characteristic. In their opinion, the brand represents the relationship between the buyer and the brand (in Filipović, 2008).

Brands are the primary connectors between an organization and its customers, the key

ingredient in building successful relationships between the company and the people it wants to serve (Schultz, Barnes, Schultz, \& Azzaro, 2015).

Lesilie de Chernatony and Malcolm McDonald put the focus of brand definition on the added value that best suits the needs of consumers (Chernatony \& McDonald, 2003).

The brand is emotional, and it has the power of "personality" and acquires the hearts and minds of its consumers (Kotler, Keller, Lalović, Lučić-Živanović, Gligorijević, \& Bogetić, 2006).

The brand represents a guarantee of quality, origin and performance, and therefore increases the perceived value of the consumer and reduces the risk and complexity that are integral to the purchase decision (Blackett, 2004).

Without the brand, the product or a service is so to speak without significance, and cannot be identified or associated with what in fact affects purchasing process. This is an overall effort of a brand identity that actually governs the success or failure; the brand image is an significant matter in understanding of its result (Mindrut, Manolica, \& Roman, 2015).

Actually, there is no unique definition of the brand, although it is assumed that the brand can be referred to as "a promise." It represents a set of elements that associate people with the brand, identify and differentiate different entities and create a unique and complex relationship with consumers. We can conclude that the brand represents identity and it refers to a specific product or service enriched with additional dimensions that make them in a certain way different from other products or services aimed at meeting the same need.

\section{BRAND ELEMENTS}

The brand includes the following elements: brand identity, brand value, brand recognition, and brand awareness.

By defining each of the mentioned elements, the brand and its basic characteristics (more precisely - its ideology) are shaped and defined. Also, in addition to the mentioned elements of the brand, it is necessary to define its appearance, i.e. the brand's visual elements.

Only with its carrier material can a brand be complete. In the constituent elements of the brand, it is possible to list everything that serves the identification of the brand in general, as well as the process of brand differentiation, in order to avoid the trap of being an ordinary product.

Brand identity - Each brand must have its own identity and vision that is related to it, which are as important to consumer perceptions as the characteristics and attributes of the product itself. That is why companies in their brands should not only see the product or service. They need to give them a wider sense in order to equate them with the whole organization in the perception of the consumers. In this case, the entire brand image is much 
wider and implies people who constitute the organization, their business culture and values. Professor David Aaker pointed out that: "It is much easier to copy a product than an organization with unique people, ideas and values" (De Chernatony \& McDonald, 2003).

Brand identity represents a set of associations that create tangible, functional, intangible and emotional properties. The mentioned brand associations include the promise that the organization offers to the end-consumers - the associations which indicate what the brand implies and what it promises to consumers. The basic elements of brand identity include visual and verbal elements. Visual identity is a system of presentations through which recognition is achieved on the market, while verbal identities represent the language of the brand. If an organization wants to bring the brand to life in consumer awareness, it is necessary to pay equal attention to the verbal and visual identity of the brand, which is equally powerful in conquering consumer awareness i.e., brand awareness.

Brand value represents an added value that is, relatively speaking, given to the products or services (Kotler \& Keller, 2006). It represents the way in which consumers perceive the brand, their thoughts when they focused on it, the emotions that the brand causes in them and their attitude toward the brand. All these elements reflect a brand's value, as well as its price, its market share and profitability.

The brand value represents an important, intangible asset that contains a psychological and financial impact which is unique for the end-consumers, as well as for the organization itself. In this sense, the brand value significantly affects the company's creditworthiness in a way that it increases its market recognition, reduces costs and the risk of entry with new products to the existing or entry of the company into the new market and it increases competitive power and advantage. Perceiving the brand value from a consumer perspective stems from the fact that the brand power rests on what customers see, read, hear, find out, think and feel when they come into contact with a certain brand (Keller, 2008).

Key benefits of brand values i.e., marketing advantages of strong brands are: Better perception of product performance; Increased loyalty; Lower sensitivity to competitive marketing strategies; Lower sensitivity to the marketing crisis; Higher margin; Inelastic consumers reaction to price hikes; Elastic consumers reaction to price reductions; Higher business cooperation and support; More effective marketing communication; Licensing opportunities (Kotler et al., 2006).

\section{BRAND IN THE FUNCTION OF MARKETING}

\section{The relationship between Marketing and Branding}

Research based on the relationship between marketing and branding is based on the fact that the most important marketing function is brand building. Moreover, many of the world's leading marketing experts point out that the basic function of marketing is brand building and management. What accelerates this trend is the steady decline of the classic type of sales, or the way in which the exchange of goods and money is carried out on the market. Today, most products on the market are not sold, but are being purchased. Consumers are directly confronted with brand products, and purchasing decisions are up to them. It is precisely in these conditions of the exchange of goods and services that marketing makes purchasing decisions much ahead of the actual exchange. A decision on whether a particular product will be purchased or not will be made by prior positioning of the product-brand itself in the 
consumer's mind. In this sense, the branding process should be understood as a thread that permeates the entire area of marketing.

\section{Branding strategy}

The basic starting point when building a brand is knowing that without a predetermined goal there is no strategy, and that the main goal of the branding strategy is to change perception. According to Kotler, \& Keller (2006: 185) perception is the process in which an individual selects, organizes and interprets input information in order to create a meaningful image of the world.

A branding strategy can be defined successfully as a selection of mutual and specific brand elements that the company applies on different products and services. It reflects the number and nature of new and existing brand elements and at the same time directs decisions on how new products will be branded (Keller, 2008). In other words, the branding strategy sets a future image whose achievement the company should strive for, giving a detailed plan of action and criteria on the basis of which it needs to be evaluated.

Usually, brand awareness bonds between strong brand and a consumer, representing a crucial role in the consumer's recalling preferred brand and finalizing positive buying decision (Farhana, 2012).

From the above mentioned, we can conclude, and at the same time confirm, the set hypothesis according to which a production branding strategy is based on future goals and end-consumer goals, and which is aimed at increasing brand awareness, creating a positive image of the brand, and establishing brand preferences and loyalty.

Building, consolidating and expanding the brand require dimensions of clarity, consistency and leadership that are adapted to the environment, with particular emphasis on competitive advantage and technology. For the purpose of harmonizing the mentioned dimensions (clarity, consistency and leadership) with a long-term perspective, the process of brand building should be directed towards achieving the following five steps: 1) Brand planning; 2) Brand analysis; 3) Brand strategy; 4) Brand building; and 5) Brand revision (Kotler, \& Pfoertsch, 2006).

\section{Brand as a tool of competitiveness}

It is widely known that solely organizations that have the capability to steadily and quickly adapt to modern business conditions, which are constantly changing, survive. In other words, only the greatest, not the strongest survive on the market. Today, the consumer expects exceptional quality, that is, fulfillment of all his needs and desires, and at the same time he is ready to only pay the price that is more favorable than the competitive one. Quality-determining characteristics represent a basic competing tool for differentiating products from those of the competition. They are at the same time one of the most important product positioning tools in "Consumer Awareness".

The brand represents a source of a competitive advantage. It can be achieved in two ways. When it comes to a product that is similar to a competitor (water, beer), the brand represents the core of differentiation. These brands need to take the leading position in the economy of scale. When it comes to a brand that has certain specific, additional values and quality for the consumer (Michelin tires, for example), the brand becomes prestigious compared to its competitors. This causes increased costs which are necessary in order to achieve consumer expectations, but it also results in higher profits. 
In order to build its position as a strong brand successfully, it needs to have a good knowledge of he-it is, also necessary to identify, analyze and monitor competitors, determine their strengths and weaknesses, and ultimately to make a selection of the competition. Upon completing such a process, the company acquires clarity and perspective, it becomes easier for them to work on media strategy, creative decision-making, and establishing a deep emotional reaction in consumer awareness, which is cited as the key to successful branding (Griffin, 2002).

Depending on the strategies, goals, strengths and weaknesses and competitor selection, a company can be classified according to the roles it offers on the target market, which we can divide into: a market leader (the company that has the largest market share compared to competitors when it comes to promotional prices, launching of new products, innovations, distribution coverage and clarity of promotion); a market challenger (companies located in the second, third or lower place in the industry, often referred to as "escorted trackers" who can attack the leaders in order to fight for a bigger market share); a market companion (companies that monitor the market leader; its product and image differentiation capabilities are small; service quality is often similar, and price sensitivity is high. Market companions can be: a forger, cloner, imitator and adapter); a market niche (an alternative to a market leader on a large market is to be a leader in a small market or a niche leader. Smaller companies generally avoid competition with larger companies by targeting small markets where large companies have little or no interest) (Kotler \& Keller, 2006).

\section{SPECIFICATIONS OF SPORTS COMMUNICATION ON THE MARKET}

From the aspect of management in sport, communication in an organization is a means of connecting people towards achieving a common goal. It is important in order to successfully accomplish all management functions. In sports, it includes a successful running of the sporting process, as well as a successful management of a sports organization as a whole. The purpose of communication lies in the purposeful direction and implementation of changes relevant to the development and improvement of the organization (Ljubojević, 2001).

For communication that exists in sports, it can be said that it fully expresses its etymological basis, because it encompasses all the natural and necessary human interaction without which human society as a whole could not function (Životić \& Veselinović, 2016).

An important condition in sports communication, which defines its success and efficiency, is that the key terms and meanings are precisely defined, that is, they do not change their meaning within the given framework.

The degree of member cooperation is needed when it is about communication that comprises the exchange of knowledge and information between group members. Members have a defined set of roles and responsibilities and are interdependent (specific to sport teams), such that the actions of team members depend on the actions of others (McLaren \& Spink, 2018).

Since communication includes permanent "encoding" and "decoding" of messages, the field of sport has been differentiated by a specific system of symbols that are combined according to the certain rules, which can be seen in correlative relationships with the four basic functions of language - informative, expressive, cohesion and practical. For the successful realization of management processes in sports, knowledge of signs and symbols in 
sports language is very important in everyday communication. To put it simply, the sporting function of each organization (training and competition) has a priority position in the management activities, that is, the sporting result as a "product" is a central issue of steering all the management potentials. In the sports arena, the specifics of the communication skills of the direct actors, that is, the skills and the speed of messages' "decoding" come into play. Knowing the meaning and essence of a particular sport discipline is a requirement for understanding and the ability to adequately monitor its effects (how to achieve points, punish illegal actions, judge gestures and symbols related to decisions during a sporting match, etc.). The communication relationship that the trainer and athletes make, i.e. athletes with each other, is the most specific area of interpersonal communication. The system of manual, verbal and associative symbols, as well as the use of everyday language, that is "jargon", but with another meaning, represents the communication specification of the sport (Gašović, 2012).

\section{TRADEMARK}

A trademark can be seen as a narrative that has freed itself of its narrative basics. It does not narrate events in their natural, chronological or in some other way and organized manner, nor does it illustrate the narrative. The word is all verbally translated into the visual. It is a visual summary of the overall corporate intention. All important messages in the trademark are dressed in pictures, drawings and symbols, and are made accessible to other human senses through the eye. The sign is seen and not "read", at least not literally; the verbal and narrative are deliberately muffled, and therefore awareness of the trademark does not owe much to the other senses (Pavlović \& Aleksić, 2012). The root of the symbolic filling of the sign rests on the potential of the eye. In successful solutions, the capture of a sign represents an eye-catcher. The earliest signs relate to the culture of the younger Paleolithic man. Cave people also had the need to express themselves concisely and metaphorically. In 1879, on the walls of the cave Altamura in Spain, paintings were found from the so-called Malden epochs, dating from 30 to 10 thousand years B.C.

The paintings show animals from the human environment (bison, wild horse, wild boar). These paintings were painted using unusually consistent colors and with a great sense of movement and they can be perceived as the first stage of visual thinking. Later periods of civilization development have significantly improved the forms of symbolic expression, and some cultures still use pictorial (ideogram) letters. For more than two thousand years, products have been marked with special signs. The Mesopotamian and Egyptian bricks carried the emblem of the place where they were made, even the construction of a building. On the tiles and bricks of old Rome, there were the names of the producers, the place of baking and the location where the clay was removed.

In ancient Greece, ceramists left clear personal marks, mostly initials. In England, in the Middle Ages, there was a legal obligation to place initials on the product, so that masters could be prosecuted if they had done their job poorly. At that time, the Guilds' Associations had their own signs, and the nobility and kings had a richer heraldic sign. The beginning of Gutenberg's era and the appearance of the first printed emblem marked a revolutionary step forward in the development of visual thinking. The formulation of the sign poetics and the demand that it should be even more concise came later (Pavlović, \& Aleksić, 2012). Today, the trademark is a very widespread and powerful means of communication between an 
organization (institution, state) and a million army of users or recipients of the message. It is an agreed, visible and easily recognizable image with multiple meanings. In the seas of messages of economic, cultural, political or personal character that spattered modern man from all sides, the sign has the function of singling our organizations from simple, easily legible and memorable means, clearly determining the origin of goods (or ideas) and being the guarantor of quality and mutual trust. A sign is a kind of password, an agreed signal that damages both parties - the sender and the recipient.

In legal terms, it distinguishes the products (services) of one organization from that of others, and literally damages it from false substitutions, injuries and forgery: "This is ours, not someone else; we own it, not someone else" (Ljubojević, 2011).

With its permanent presence, the modern trademark communicates on several levels. On the most general plan, the signs humanize and aesthetize the ambience through the language of fine arts. By adding an aesthetic quality to the product ("Value that remains"), the sign helps to create and protect its position in the market and enhance its presence on the shelves. Knowing that visual messages are an important factor in corporate identity, serious firms foster thoughtful care of the security loop and other elements of graphic communication. This is best seen at ceremonies, annual conferences or press conferences where the general manager and representatives of the board of directors are greeted cheerfully in front of the glittering signs and logos, crowned with gold, silver or some other stainless material. Once, in the Wild West, hit by voles and horses with a sealed or stamped seal - trademarks are now created so that they can be applied in any position and in any size. The visual value of the sign is based on the unity of its aesthetic, functional and content elements.

Regardless of whether realistic or abstract processing is prevailing in it, whether they symbolize the human, animal or plant world, the trademark must be simple, specific, and original in its expression. When it first appears, the best sign is not able to concentrate on all the ideas, associations and cultural experiences of the diverse human population, but only on some of them. If it is simple, graphically pure, memorable and constructively perfect, the trademark will, by continuity and repetition, become a recognizable image worldwide.

\section{CONCLUSION}

The basic purpose of this research is based on the analysis of scientific-theoreticalpractical knowledge in the field of brand management, with a special emphasis on the brand as a significant factor of organizational competitive advantage and establishing a leading position in the sports market. During the research, hypotheses are set up and we conclude that achieving success in building a particular brand represents a process that takes time and patience. Branding strategy requires dedication and perseverance, and most importantly the establishment of a leader brand; someone who takes responsibility to ensure that what is called the "brand promise" will always be met.

The brand represents an important tool in achieving a competitive position on the market. It is a prism through which consumers look at everything about the company, the products and services and form their own conclusions. Brand management is a process that should ensure positive associations, beliefs and expectations of consumers in their communication with the brand. 
The emotional experience that consumers have in contact with the brand is crucial to creating long-term loyalty. Many brands achieve all functional qualities, but a small number of them communicate with consumers on an emotional level. All larger world brands have an exceptional emotional impact on their consumers. They inspire them, they move them and give their lives a new meaning.

Creating a strong and recognizable brand represents an imperative for all companies and their products and services on the market. The brand creates a relationship with consumers by telling its story in a certain way. The new millennium provides new ways of developing a brand, and everything a company needs to do is to accept the changes brought about by the new era and take advantage of its benefits. For brands that are ready for constant change, there are no limits.

\section{REFERENCES}

Blackett, T. (2004). What is a brand? In: R. Clifton \& J. Simmons (Eds.), Brands and branding, (pp. 13-26). London: Profile Books Ltd.

De Chernatony, L., \& McDonald, M. (2003). Creating powerful brands in consumer, service and industrial markets, Elsevier, Butterworth Heinemann

De Chernatony, L., \& Riley, F.D.O. (1998). Modelling the components of the brand. European Journal of Marketing, 12 (11-12), 1074-1090.

Farhana, M. (2012). Brand elements lead to brand equity: Differentiate or die. Information Management and Business Review, 4(4), 223-233.

Filipović, V. (2008). Brend menadžment (Brand management). Belgrade: Faculty of Organizational Sciences, University of Belgrade. In Serbian

Gašović, M. (2012). Marketing sportskih organizacija (Marketing of sports organizations). Belgrade: Interma Net. In Serbian

Griffin, J.J. (2002). To brand or not to brand? Trade-offs in corporate branding decisions. Corporate Reputation Review, 5(2-3), 228-240.

Keller, K.L. (2008). Strategic brand management. UK: Prentice Hall.

Kotler, P., \& Keller, K.L. (2006). Marketing management (Twelefth Edition). USA: Prentice Hall, Inc.

Kotler, P., Keller, K.L., Lalović, B., Lučić-Živanović, M., Gligorijević, B., \& Bogetić, Z. (2006). Marketing menadžment (Marketing management). Data status. In Serbian

Kotler, P., \& Pfoertsch, W. (2006). B2B brand management. Springer Science \& Business Media.

Ljubojević, Č. (2001). Menadžment $i$ marketing u sportu (Management and marketing in sports). Belgrade: Želnid d.o.o. In Serbian

McLaren, C.D., \& Spink, K.S. (2018). Examining communication as information exchange as a predictor of task cohesion in sport teams. International Journal of Sport Communication, 11(2), 149-162.

Milić, S. Proces izgradnje Brenda (The process of building a brand). Ekonomski signali, 9(2), 33-47. In Serbian

Mindrut, S., Manolica, A., \& Roman, C.T. (2015). Building brands identity. Procedia Economics and Finance, $20,393-403$

Klein, N. (2010). No Logo at 10. The Baffler, $2(1$ [18), 30-39.

Olins, W. (2003). On brand. London: Thames \& Hudson.

Pavlović, M., \& Aleksić, M. (2012). Odnosi s javnošću (Public relations). Belgrade: Megatrend University. In Serbian

Rushkoff, D. (2010). Program or be programmed: Ten commands for a digital age. New York: Or Books.

Schultz, D., \& Barnes, B.E. (1999). Strategic brand communications campaigns. NTC Business Books: Chicago.

Schultz, D.E., Barnes, B.E., Schultz, H.F., \& Azzaro, M. (2015). Building customer-brand relationships. Routledge.

Životić, D., \& Veselinović, J. (2016). The significance of the organizing process in sports organizations. Facta Universitatis Series Physical Education and Sport, 14(2), 307-313. 


\section{BRENDIRANJE I BREND KAO FAKTOR KONKURENTSKE PREDNOSTI U SPORTU}

Svrha ovog istraživanja zasniva se na analizi naučno-teorijsko-praktičnog znanja iz oblasti upravljanja brendom, sa posebnim naglaskom na brend kao značajnim faktorom organizacione konkurentske prednosti $i$ vodeće pozicije na sportskom tržištu. Istraživajući veliki broj različitih teorijskih saznanja,nailazimo na definicije koje se zasnivaju na stavovima vodećih svetskih marketinških eksperata koji ističu da je osnovna funkcija marketinga upravo izgradnja brenda. Izgradnji, konsolidaciji i ekspanziji brenda potrebne su dimenzije jasnoće, konzumentnosti i liderstva, prilagođene uslovima sredine, sa posebnim naglaskom na konkurentskoj prednosti, tehnologiji i uspostavljanju liderske pozicije na tržištu.Pozivajući na adekvatnu literaturu, obuhvaćena je kompletna strategija proizvodnog brendiranja, polazeći od uopštenih koje strategije brendiranja definišu kao najmoćniji instrument komunikacije; posebnih koje se baziraju na definicijama da je ključ uspeha ostvarenje konkurentske prednosti $i$ uspostavljanje liderske pozicije na tržištu; do pojedinačnih koje istražuju osnovne elemente strategije brendiranja i njihov uticaj na poslovne kompanije, njihove produktivnosti $i$ uticaja na svest krajnjih potrošača.

Ključne reči: brend, zaštitni znak, konkurentska prednost 